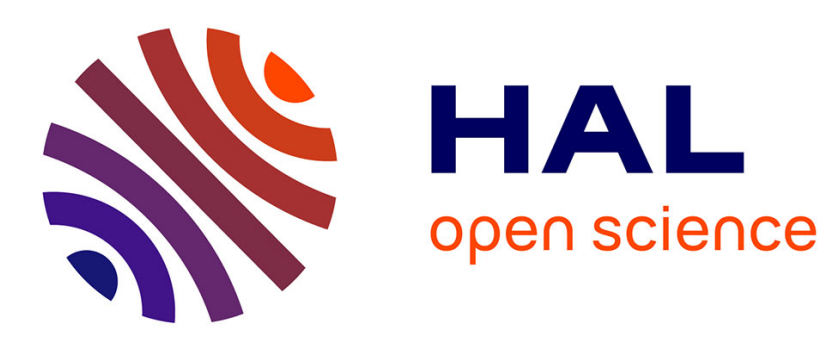

\title{
Dynamic Behavior of a Shock-Loaded Glass-Ceramic Based on the Li2O-Al2O3-SiO2 System
}

M. Hiltl, H. Nahme

\section{To cite this version:}

M. Hiltl, H. Nahme. Dynamic Behavior of a Shock-Loaded Glass-Ceramic Based on the Li2OAl2O3-SiO2 System. Journal de Physique IV Proceedings, 1997, 07 (C3), pp.C3-587-C3-592. 10.1051/jp4:19973101 . jpa-00255385

\section{HAL Id: jpa-00255385 https://hal.science/jpa-00255385}

Submitted on 1 Jan 1997

HAL is a multi-disciplinary open access archive for the deposit and dissemination of scientific research documents, whether they are published or not. The documents may come from teaching and research institutions in France or abroad, or from public or private research centers.
L'archive ouverte pluridisciplinaire HAL, est destinée au dépôt et à la diffusion de documents scientifiques de niveau recherche, publiés ou non, émanant des établissements d'enseignement et de recherche français ou étrangers, des laboratoires publics ou privés. 


\title{
Dynamic Behavior of a Shock-Loaded Glass-Ceramic Based on the $\mathrm{Li}_{2} \mathrm{O}-\mathrm{Al}_{2} \mathrm{O}_{3}-\mathrm{SiO}_{2}$ Systerı
}

\author{
M. Hiltl and H. Nahme \\ Fraunhofer-Institut für Kurzzeitdynamik, Ernst-Mach-Institut, Eckerstrasse 4, 79104 Freiburg, Germany
}

\begin{abstract}
The dynamic behavior of the Robax glass-ceramic based on the $\mathrm{Li}_{2} \mathrm{O}-\mathrm{Al}_{2} \mathrm{O}_{3}-\mathrm{SiO}_{2}$ system has been investigated. The experiments were performed using the planar impact technique in combination with a VISAR interferometer. From the velocity-time profiles the Hugoniot elastic limit $\sigma_{\mathrm{HEL}}$, spall strength $\sigma_{\mathrm{sp}}$ and strains $\varepsilon$ have been calculated. The results are plotted in $U_{s}-u_{p}, \sigma_{\max }-\varepsilon$ and $\sigma_{\mathrm{sp}}-\sigma_{\max }$ diagrams and fitted with linear relations. At stresses above $9 \mathrm{GPa}$ the existence of a failure wave in the glass-ceramic is observed.

Résumé: Le comportement dynamique de la céramique de verre Robax basé sur le système $\mathrm{Li}_{2} \mathrm{O}-\mathrm{Al}_{2} \mathrm{O}_{3}-\mathrm{SiO}_{2}$ a été examiné. Les expériences ont été effectuées en utilisant la technique d'impact planaire en combinaison avec un interféromètre VISAR. A partir des profils de vitesse, on a calculé la limite élastique d'Hugoniot $\sigma_{\mathrm{HEL}}$, la force d'écaillage $\sigma_{\mathrm{sp}}$, et les contraintes de déformation $\varepsilon$. Les résultats sont contenus dans des diagrammes $U_{\overline{\mathbf{s}}} u_{\mathrm{p}}, \sigma_{\max }-\varepsilon$ et des diagrammes $\sigma_{\mathrm{sp}}-\sigma_{\max }$ assortis de relations linéaires. A des niveaux de contrainte supérieurs à $9 \mathrm{GPa}$ l'existence d'une onde d'échec est observée dans la céramique de verre.
\end{abstract}

\section{INTRODUCTION}

Glass-ceramics are polycrystalline materials formed by a controlled crystallization of a suitable base glass [1]. The materials based on the $\mathrm{Li}_{2} \mathrm{O}-\mathrm{Al}_{2} \mathrm{O}_{3}-\mathrm{SiO}_{2}$ system have found a wide-spread application and achieved a great economic importance due to the very low thermal expansion coefficient (CTE) and other excellent mechanical properties [2]. Because only very little is known about the dynamic behavior under shock-loading, the glass-ceramic Robax made by the Schott Glaswerke Mainz/Germany has been investigated under shock conditions. Robax is a highly transparent substance with a minimal amount of coloration, depending on the production conditions. The crystallite size is approximately $50 \mathrm{~nm}$. The material has a high mechanical strength and heat resistance [3]. Some technical data are given in Table 1.

\begin{tabular}{|c|c|}
\hline Density $\left(\rho_{0}\right)$ & $2,56 \mathrm{~g} / \mathrm{cm}^{3}$ \\
\hline Porosity & $0 \%$ \\
\hline Young's modulus (E) & $92 \mathrm{GPa}$ \\
\hline Longitudinal sound velocity (c) & $6570 \mathrm{~m} / \mathrm{s}$ \\
\hline Thermal expansion coefficient (CTE) & $20-700^{\circ} \mathrm{C}: 0,1 \bullet 10^{-6} / \mathrm{K}$ \\
\hline
\end{tabular}




\section{EXPERIMENTAL SETUP}

The planar impact technique in combination with a VISAR interferometer [4] have been used to investigate the dynamic behavior of the Robax glass-ceramic under shock-loading. These experiments are frequently used to achieve high pressures, high stresses and high strain rates under well characterized conditions [5]. The $58 \mathrm{~mm}$ in diameter and $3 \mathrm{~mm}$ thick C45-steel projectile plates have been accelerated to velocities up to $1058 \mathrm{~m} / \mathrm{s}$ using a single stage gun with $70 \mathrm{~mm}$ bore diameter. A thin layer of Aluminum was sputtered on the rear surface of the transparent $50 \mathrm{~mm}$ square and $4.82 \mathrm{~mm}$ thick Robax target plates to obtain diffuse reflected laser light from the surface. The experimental setup immediately before planar impact is schematically shown in Figure 1. The impact of the projectile plate on the fixed target plate causes elastic and plastic waves. The waves are reflected at the free surfaces back into the materials as pressure release waves. The superposition of the waves inside the target produces tensile stresses, which damages the material. The free surface velocity of the target rear side was measured with a VISAR interferometer.

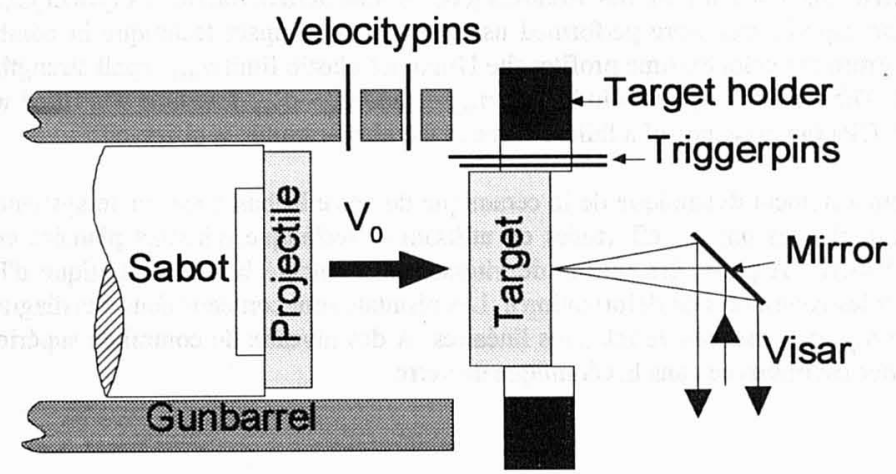

Figure 1: Schematic experimental setup

From the velocity-time records the Hugoniot Elastic Limit $\sigma_{\mathrm{HEL}}$ was determined according to

$$
\sigma_{\mathrm{HEL}}=\frac{\rho_{0} \mathrm{c}_{1} \mathrm{u}_{\mathrm{HEL}}}{2}
$$

with the density of the Robax material $\rho_{0}$, the longitudinal sound velocity $c_{1}$ and the amplitude of the elastic precursor $u_{\mathrm{HEL}}$. The spall strength $\sigma_{\mathrm{sp}}$ is determined from the relation

$$
\sigma_{\mathrm{sp}}=\frac{\rho_{0} \mathrm{c}_{1} \Delta \mathrm{u}_{\mathrm{sp}}}{2}
$$

with the pull back signal $\Delta \mathrm{u}_{\mathrm{sp}}$. The maximum stress $\sigma_{\max }$ was calculated using

$$
\begin{aligned}
& \mathrm{U}_{\mathrm{S}}=\frac{\mathrm{c}_{1}}{\left(\frac{1+\mathrm{c}_{1} \Delta \mathrm{t}}{\mathrm{d}_{\mathrm{T}}}\right)} \\
& \sigma_{\max }=\frac{\rho_{0}\left(\mathrm{c}_{1} \mathrm{u}_{\mathrm{HRL}}+\mathrm{U}_{\mathrm{s}}\left(\mathrm{u}_{\max }-\mathrm{u}_{\mathrm{HEL}}\right)\right)}{2}
\end{aligned}
$$


where $U_{\mathrm{s}}$ is the shock velocity, $d_{T}$ the target thickness, $\Delta t$ the time interval between elastic and plastic wave and $u_{\max }$ the maximum velocity. The maximum strain $\varepsilon_{\max }$ and strainrate $\dot{\varepsilon}$ are calculated using

$$
\begin{aligned}
& \varepsilon_{\max }=\left(\frac{u_{\text {HEL }}}{2 c_{1}}\right)+\left(\frac{u_{\text {max }}-u_{\text {HEL }}}{2 U_{s}}\right) \\
& \dot{\varepsilon}=\left(\frac{u_{\max }-u_{\text {HEL }}}{2 U_{s} \Delta t_{1}}\right)
\end{aligned}
$$

with the time interval between the elastic and plastic wave $\Delta t_{1}$.

\section{EXPERIMENTAL RESULTS AND DISCUSSION}

A total of 22 impact experiments with impact velocities $103 \mathrm{~m} / \mathrm{s}<\mathrm{v}_{0}<1058 \mathrm{~m} / \mathrm{s}$ were carried out with the Robax glass-ceramic material. Typical free surface velocity-time histories measured with the VISAR interferometer at different impact velocities are given in Figure 2.

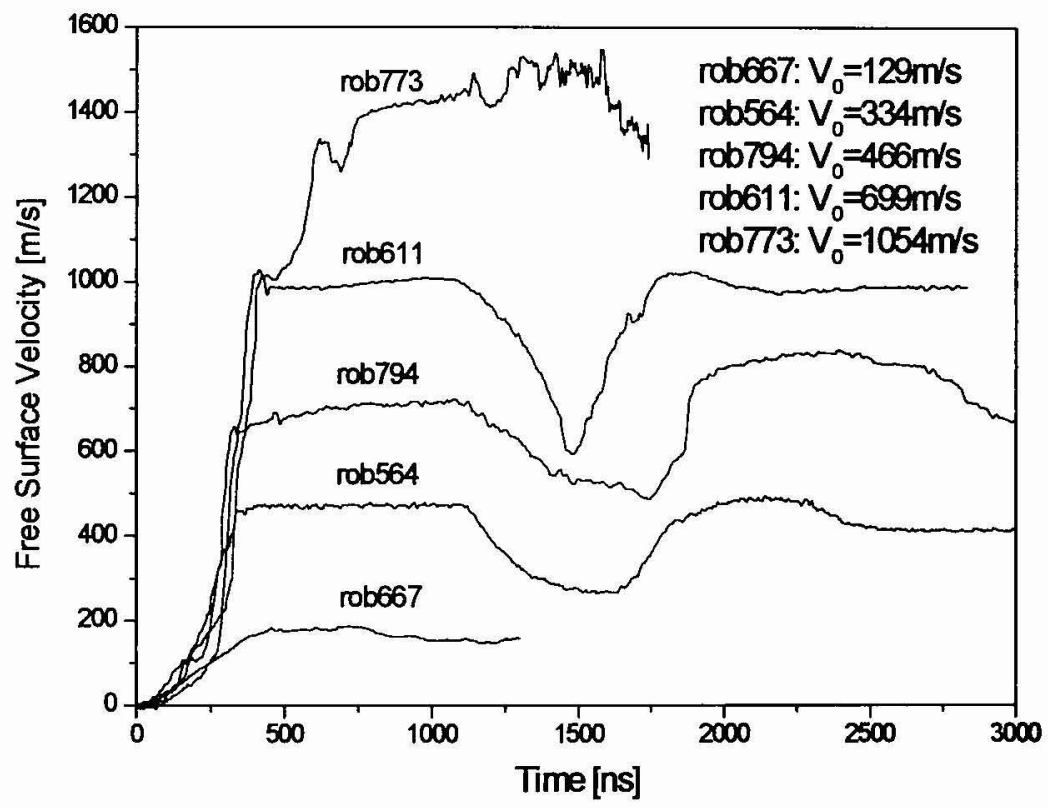

Figure 2: Velocity-time histories for Robax

The curves show an elastic precursor yielding a low Hugoniot elastic limit $\sigma_{\mathrm{HEL}}$ of $900 \pm 150 \mathrm{MPa}$ which is followed by a further increase due to the plastic wave. Robax shows clear spall signals and in some cases 
the so called ringing in spall occurred. Figure 3 shows the spall strength $\left(\sigma_{\mathrm{sp}}\right)$ versus stress $\left(\sigma_{\max }\right)$ diagram. A linear least square fit yields

$$
\sigma_{s p}=-0.45 \pm 0.24+0.65 \pm 0.06 \sigma_{\max }
$$

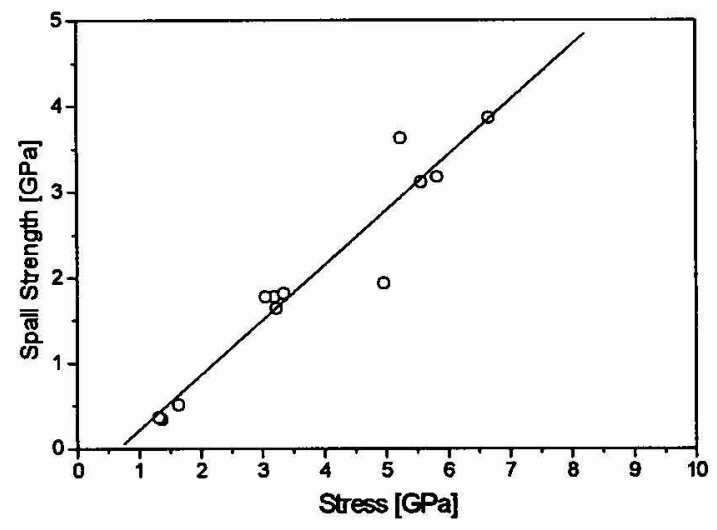

Figure 3: Spall strength-stress diagram

The relationship between the shock velocity $\left(U_{s}\right)$ and the particle velocity $\left(u_{p}\right)$ is graphically shown in Figure 4 . The data set can be described by a linear regression

$$
\mathrm{U}_{\mathrm{s}}=\mathrm{C}_{0}+\mathrm{Su}_{\mathrm{p}}
$$

where $C_{0}$ is $5377 \pm 70 \mathrm{~m} / \mathrm{s}$ and $\mathrm{S}$ is $-0.52 \pm 0.15 \mathrm{~m} / \mathrm{s}$.

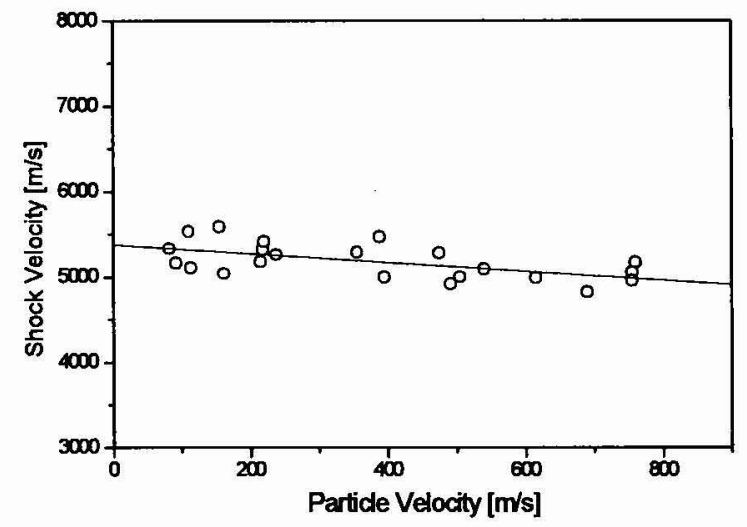

Figure 4: Shock velocity vs. particle velocity diagram

The maximum stress -strain loading behavior of the Robax glass-ceramic is depicted in Figure 5 and the relation is fitted with a linear regression by

$$
\sigma_{\max }=0.65 \pm 0.11+0.62 \pm 0.01 \varepsilon
$$




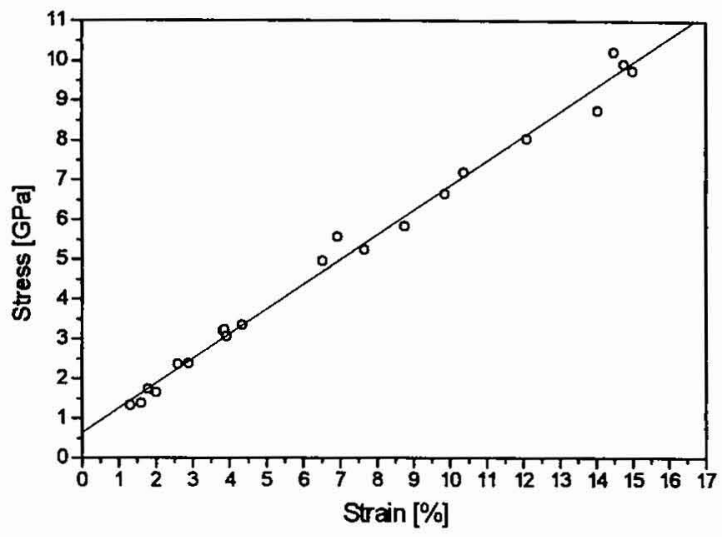

Figure 5: Stress-strain diagram

From the velocity time histories (Figure 2) it can be seen that at pressures above 9 GPa no spallation was wbserved. Instead two significant steps appear in the velocity history of test rob773 at $500 \mathrm{~ns}$ and $600 \mathrm{~ns}$ respectively. The nature of the small velocity decrease that accompanies the second step is not understood at present. The two steps in the velocity profile can be interpreted as a failure wave propagation in the Robax glass-ceramic. The existence of failure waves in glass under uniaxial conditions is reported by Kanel et al. [6], Raiser and Clifton [7] and Brar et al. [8]. Nahme et al. [9] assume a failure wave in porous $\mathrm{Si}_{3} \mathrm{~N}_{4}$. Kanel et al. presume that the failure wave is a network of cracks initiated by the compression.

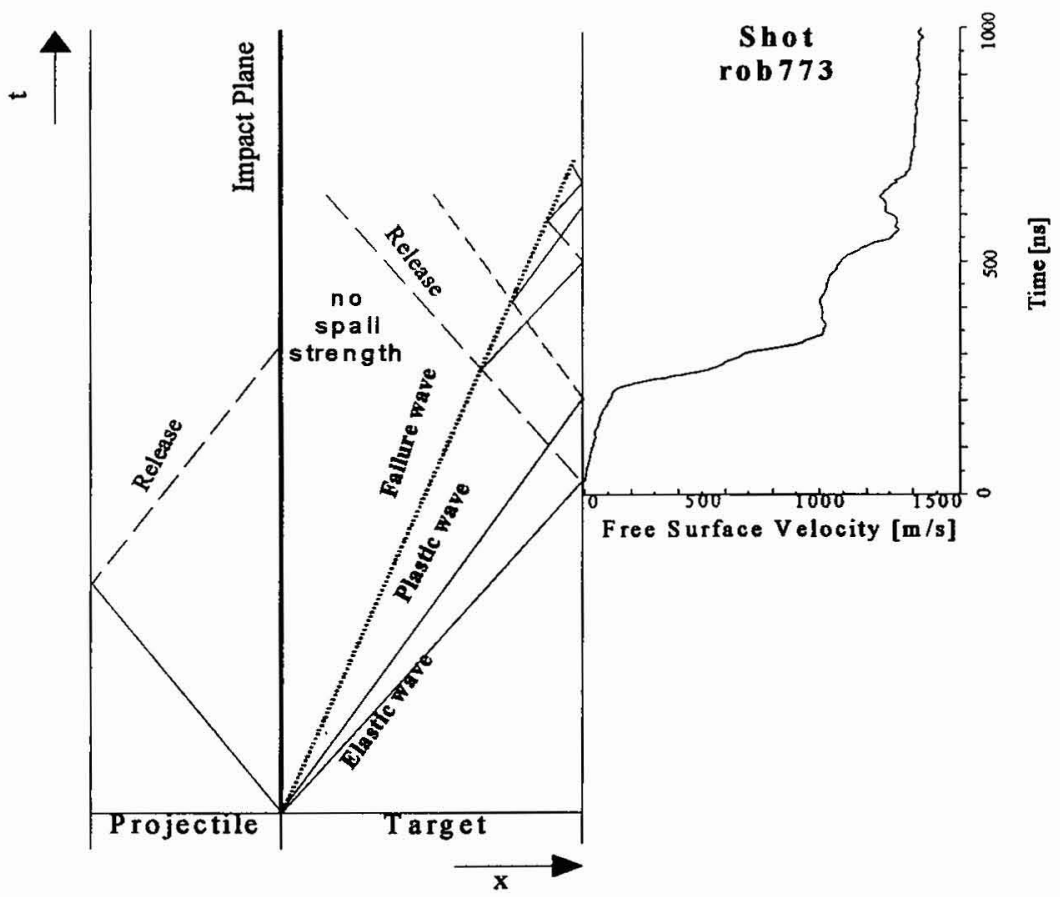

Piigure 6: Lagrangian X- t- diagram and velocity-time curve of shot rob773 showing elastic, plastic and failure waves 
Figure 6 shows the Lagrangian X-t diagram for test rob773. It can be seen that first the elastic wave arrives at the rear surface of the material and produces an increase in the velocity. The elastic wave is reflected back from the surface as a release wave. Immediately after the elastic wave is reflected, the slower plastic waves appear and cause a rapid jump in the velocity profile. The elastic release wave is reflected at the failure wave effecting the increase in the velocity around $500 \mathrm{~ns}$. The failure wave damages the material before tensile stresses due to the superposition of release waves can occur. Because of this, no spall signal can be observed in the velocity profiles at the experiments above a stress of 9 GPa.

\section{CONCLUSION}

Using the planar impact technique in combination with a VISAR interferometer, the shock wave propagation in the transparent Robax glass-ceramic based on the $\mathrm{Li}_{2} \mathrm{O}-\mathrm{Al}_{2} \mathrm{O}_{3}-\mathrm{SiO}_{2}$ system was studied. The Hugoniot Elastic Limit $\sigma_{\mathrm{HEL}}$ was determined to be $900 \pm 150 \mathrm{MPa}$. From the velocity-time histories of the VISAR measurements $U_{s}-u_{p}, \sigma_{\max }-\varepsilon$ and $\sigma_{s p}-\sigma_{\max }$ diagrams have been plotted. Above a stress level of $9 \mathrm{GPa}$ a failure wave occurs in the Robax glass-ceramic and therefore no spall signals can be observed in the velocity history profiles.

\section{REFERENCES}

[1] McMillan, P. W., "Glass-Ceramics", Academic Press (1979)

[2] Scheidler, H., Rodek, E., Am. Ceram. Soc. Bull. 68 (1989) 1926-1930

[3] Strnad, Z., "Glass-Ceramic Materials", Elsevier (1986)

[4] Barker, L. M., Hollenbach, R. F., J. Appl. Phys. 43 (1972) 4669-4675

[5] Meyers, M. A., "Dynamical Behavior of Materials", John Wiley \& Sons (1994)

[6] Kanel, G. I., Rasorenov, S. V., Fortov, V. E., "The Failure Waves and Spallations in Homogeneous Materials" Shock Compression of Condensed Matter 1991, Schmidt, S. C. Dick, R. D., Forbes, J. W., Tasker, D. G. (editors) pp. 451-454

[7] Raiser, G., Clifton, R. J., "Failure Waves in Uniaxial Compressions of an Aluminosilicat Glass", Shock Compression of Condensed Matter 1993, Schmidt, S. C., Shaner, J. W., Samara, G. A., Ross, M. (editors) pp. 1039-1042

[8] Brar, N. S., Bless, S. J., Rosenberg, Z., "Spall Strength and Failure Waves in Glass", J. de Physique IV, 1991, pp. C3-639

[9] Nahme, H. Hohler, V. Stilp, A., " Dynamic Material Properties and Thermal Ballistic Behaviour of Shock-Loaded Silicon-Nitride Ceramics, J. de Physique IV, 1994, pp. C8-237 